Article

\title{
Religion and the Limits of Metatheatre in Our Town and Sunday in the Park with George
}

\author{
Larry D. Bouchard
}

Department of Religious Studies, University of Virginia, Charlottesville, VA 22904, USA; ldb4k@virginia.edu

Received: 31 December 2019; Accepted: 10 February 2020; Published: 18 February 2020

\begin{abstract}
This essay explores theatrical drama alongside aspects of religious dimensionality David Tracy analyzes in terms of limit experience, limit language, and limit questions. The claim is that metatheatrical forms can correlate with limit dimensions, a correlation which may prove as pertinent as ritual for linking drama with religious experience, thought, and practice. Here, metatheatre and limit dimensions are further defined in respect to Thornton Wilder's 1938 play, Our Town, and Stephen Sondheim and James Lapine's 1984 musical, Sunday in the Park with George. The essay identifies distinct though often overlapping forms of metatheatre: plays or performances that (1) explicitly refer to themselves, or (2) represent theatrical or theatre-like works within their stories and expressed worlds (e.g., plays within plays), or (3) dramatize theatre-like and performative aspects of ordinary life. Just as Wilder foregrounds metatheatrical relations to create an impression of the eternal, Sondheim and his collaborators reflect on their work's ontological conditions of possibility by bringing to life another work, a painting, at distantly separated moments in time. Our Town and Sunday in the Park invite us to enter social and ritualized spaces inhabited by commonplace yet archetypal persons; they culminate in moments where the audience is to discern past, present, and future in simultaneous proximity; and with their different contents and forms, they prove good plays for elaborating relations among theatre, limit experience, and religious dimensionality.
\end{abstract}

Keywords: metatheatre; limit experience; religious dimensionality; Wilder; Sondheim; Lapine

In this wedding I play the minister. That gives me the right to say a few more things about it.

For a while now, the play gets pretty serious. [. . .]

And don't forget all the other witnesses at this wedding, - - the ancestors. Millions of them.

- Stage Manager to audience, Our Town

(Indicates painting)

But this is our family tree.

Just wait till we're there and you'll see-

-Marie to Elaine, Sunday in the Park with George ${ }^{1}$

\section{Introduction}

Theatrical drama is a hybrid genre of live performance before a live audience and a story or script composed with the aim of enactment. A feature of theatrical drama that may prove pertinent to religious experience is metatheatre. Notice, in the first epigraph, how the Stage Manager speaks to us,

1 Wilder 1957; Sondheim and Lapine 1986; future page citations parenthetical. As both plays employ ellipses (...), my ellipses in all quotations are bracketed [. . .]. 
the audience, about the play in which he also performs various minor characters-here, a minister at a wedding. Since we are also witnesses at this wedding, there is a sense in which we are among the "ancestors," and so the significance of our role in this wedding is enlarged pretty seriously. Metatheatrical relations in the second passage are more complex. The elderly Marie gestures to a large painting in Act II, which defined the social world of Act I, a century before. She claims to have been "in" the painting as an infant, and now she plans to visit what remains of its world, her ancestors, in Paris. Although addressing Elaine, her "you'll see" addresses us as well. Seeing, as perception and involved discernment, is crucial to the theatrical forms and revelations of both plays.

This essay explores drama and metatheatre alongside aspects of religious dimensionality David Tracy analyzes in terms of limit experience, limit language, and limit questions. ${ }^{2}$ My claim for theatrical drama will be that metatheatrical forms can correlate with 'limit dimensions,' a correlation that may prove as pertinent as ritual for linking drama with religious experience, thought, and practice. ${ }^{3}$ Metatheatre, or theatre reflecting itself as theatre, entered the critical vocabulary with Lionel Abel (1963) in reference to what he termed metaplays, especially by Shakespeare, Calderon, and the modernist Luigi Pirandello. ${ }^{4}$ While Abel was at pains to distinguish metatheatre from an Aristotelian view of tragic realism, I find it difficult to locate theatrical drama in any period that is not at least implicitly meta. Metatheatre also jibes with but predates modern self-reference and postmodern intertextuality, with which it is often conflated. ${ }^{5}$ Play, audience, and players are always there together, generating reflexive references.

Here, I further define and nuance metatheatre and limit dimensions in respect to Thornton Wilder's 1938 play and Stephen Sondheim and James Lapine's 1984 musical. Just as Wilder consternated American drama by banishing naturalist staging and foregrounding metatheatrical relations, Sondheim and his collaborators "reinvented" the American musical. ${ }^{6}$ The analogy is complicated, however, in that musicals have always foregrounded metatheatre through their 'numbers' - that is, their featured songs which address the audience as much as the characters in the story. Sondheim takes the integrated musical (a fusion of song with plot and character) and makes it self-reflective of its own existential realism ${ }^{7}$ and, I would add, idealism, much as does Wilder's metatheatre. In particular, in Our Town and Sunday in the Park with George we enter social spaces inhabited by commonplace yet archetypal persons. Both plays culminate in moments where the audience is to discern past and present in simultaneous proximity to something like eternity. Thus, despite their different contents and forms, these are good plays for elaborating relations among metatheatre, limit experience, and religious dimensionality. If Our Town is a paradigm case for these relations, it may be that Sunday in the Park serves as a 'limit case' or, better, a 'case of limits.'

\section{Limit Experience and Metatheatre 1, 2, 3}

Metatheatre, in plays as written and as performed, is a matter of encountering limits and crossing boundaries. So metatheatre lends itself, prima facie, to limit dimensions in experiences construed as

2 Tracy 1975, pp. 92-103.

3 A central issue in religion and arts is how a work with specific genre traits-a lyric poem, painting, novel, sculpture, oratorio-generates effects (aesthetic, affective, semantic) through its form (actually a hybrid of forms) at intersections with religion. Elsewhere I sketch approaches to religion and art to keep 'in play' — phenomenological, hermeneutical, historical, and deconstructive-in my "Religion and Literature: Four Theses and More" (Bouchard 2009). The present essay elaborates my suggestion that metatheatre can link drama to religion via limit questions, such as "Why theatre?" or "Why humanity?" in "Dramatic Ways of Being Religious" (Bouchard 2014).

$4 \quad$ Abel 1963, 2003.

5 See Konkle, 2018, on Our Town and The Skin of Our Teeth "as Proto-Postmodern Drama." He cites Mudasir 2011: “[P]ostmodern drama foregrounds the notion of 'self-reflexive referentiality'" (nearly a definition of metatheatre).

6 McLaughlin 2016.

7 McLaughlin understands Sondheim musicals to be contextualized by postmodernism (p. 27), with Sunday in the Park also reclaiming the realism of how artifice can capture "the dynamic, fluid chaotic world" (p. 167). 
religious, spiritual, moral, sacred, numinous, mysterious, and the like. Tracy does not define religion as limit but notices that where we find religion, howsoever defined, we tend to find limit phenomena.

Easiest to visualize are limit questions, which ask about conditions for the possibility of the domain from which the question arises. For instance, "Why physics?" can be asked within physics if the why seeks a causal (physical-mathematical) explanation. Yet "Why physics?" asks about the conditions for the possibility of physical causation itself; it is a question about the very meaning of physics and thus points beyond its limit or horizon. Diagram physics as a circle, and the question can be an arrow starting from within physics and arcing over the limit into an undefined area. Queries like "Why chemistry?" point to physics, the limit-of chemistry, for their terms are congruent. Whereas "Why physics?" would require different language altogether (philosophical, mythical, poetic). Tracy takes up another question, "Why morality" or "Why be ethical?" Again, the terms come from ethics, so the question is not meaningless in its domain, yet its arrow points 'beyond' ethical discourse. "[W]e cannot really produce a moral argument for being moral." 8

For Tracy, two sorts of experiences go with limit questions. We can construe "limit-to" as encountering a given domain's horizon from within. It is a felt as well as logical limit; "why keep promises?" pushes us up to a sense of morality's edge. Yet "limit-of" experiences infer an 'other side' of the limit, now felt as a horizon opening into ontological uncertainty. Logically odd forms of language often accompany religious limit-of experiences: symbol, metaphor, myth, prophecy, mysticism, articulating beliefs or practices purporting to 'answer' limit-to questions. In Christianity, grace (limit-of) transforms situations of sin and finitude (limit-to). In Hinduism, moksha (experienced as limit-of) releases one from the karmic cycle of births and deaths, samsara (limit-to). By itself, however, the logic of limit does not necessitate that limit-of experiences be liberating, transformative, or trust filling. A symbolism 'beyond the limit' might bode nemesis, chaos, threat, tragic fate, and undermine 'basic trust' in reality. ${ }^{9}$

Metatheatre's 'limits' need not be religious or mysterious and rarely make us ponder 'conditions for the possibility' of theatre. Metatheatre wants to delight and intrigue. But its analogy to limit experience is in the play-within-a-play structure. Since the outer play frames the inner play, it is like the limit-of area beyond the inner play. The world of Hamlet frames "The Murder of Gonzago," or "Mousetrap." The world of Our Town frames George and Emily's wedding. Sunday in the Park with George is more complex. From one angle, the Chromolume device in Act II, an electronic light sculpture, is limit-of for the pointillist painting from Act I, simply because the Chromolume 'refers' to (projects images or impressions from) Georges Seurat's A Sunday Afternoon on the Island of La Grande Jatte. From another angle, it is the painting - source of Act I's characters-that frames Sunday in the Park. The musical is figuratively a play within a painting, which is literally a painting within this play. ${ }^{10}$ Yet metatheatre is not always a play within a play. When the Stage Manager tells us about Our Town, we become the frame of this play, indicative of its 'beyond,' and participate-more than audiences usually do-in its limit-of dimension. The "our" of the title, like the "in" and "with" of Sunday in the Park with George, signals our being incorporated into these worlds while remaining at a distance from them, at their limits.

It may well be that all theatrical drama is implicitly metatheatrical. Theatre demarcates and crosses differences between show and non-show, appearance and reality, script and performance,

8 Tracy 1975, p. 102; his analyses of limit credit philosopher Stephen Toulmin on the issue.

9 On Tracy and limit-of, see Shapiro 1983, pp. 6-7. On the tragic vision: see Ricoeur 1967, pp. 211-31. For Victor Turner in "Betwixt and Between," Turner 1967, liminality in rituals and social dramas can involve dangerous passages across limits, passages often framed by religious or quasi-religious lore. See his also his analysis of 'social dramas' and the story of Thomas Becket (Turner 1974, pp. 60-97).

10 The play also recapitulates meta aspects of the painting. On the $10^{\prime} \times 6.5^{\prime}$ painting itself, see Herbert and Harris 2004 , cited further below. McLaughlin 2016, p. 154, observes that as the play begins, it shows that Seurat, the figures he composes, and "the audience, are always both inside and outside the painting." 
stage spaces and other spaces, show time and other times, ${ }^{11}$ persons playing persons and persons playing roles. Nevertheless, metatheatre becomes a more distinctive feature when it intensifies our awareness of such crossings and stimulates thought and feeling. I have found it useful to distinguish three overlapping sorts of metatheatre:

Metatheatre-1 (MT-1) comprises times when a play or performance more-or-less explicitly refers to itself, as with Wilder's Stage Manager and Vivian in Margaret Edson's Wit. Shakespeare's soliloquies and asides play as MT-1, inviting us into the play or into a character's (or actor's) 'theatre of the mind.' Brecht's alienation effects and placards can be MT-1 in Galileo ("You will not resent, we hope, The truth about his telescope"12); so too the numbers or songs in musicals. MT-1 ('breaking the fourth wall,' though all metatheatre does that) makes apparent the limit or edge of the play's 'world.' The audience is made distant yet close to this edge; in effect, we become part of the play's limit-of. ${ }^{13}$ Sometimes, a play's edge draws attention to limits and horizons of our worlds-or such reflecting may happen simply as a matter of course.

Metatheatre-2 includes other edges: performances within performances, the outer becoming limit-of for the inner. Plays-within inevitably mirror the framing play and, again, can evoke questions about limit dimensions in our worlds-as with Hamlet. In staging Mousetrap, Hamlet is testing both his uncle's moral guilt (limit-to) and the nature of the Ghost ("spirit of health or goblin damned"-limit-of). In Suzan-Lori Park's Venus, the exhibitions (theatrical and 'scientific') of Saartjie Baartman also fit MT-2. So may performances other than theatrical in a story: thus Nora's dancing the Tarantella to distract her husband in Ibsen's Doll's House. Trial scenes can be MT-2, such as the mock trial in Lear. The sheep deception in the medieval Second Shepherds' Play looks like MT-2. So does Dionysus in Euripides' Bacchae, when he tells us he is a god impersonating a mortal; we are in MT-1 and near MT-2.

Metatheatre-3 is less straightforward. It draws attention to theatrical and performative dimensions of ordinary life, where "life is a dream" (Calderon) or "all the world's a stage" (Shakespeare). The world stage includes 'parts we play' and social or vocational roles, often overlapping and hybridized, with codes and ideologies. ${ }^{14}$ Every role, action, and reception implies a temporal-social-cultural world of limits and horizons, surpassable and unsurpassable. ${ }^{15}$ MT-3 also spotlights performative action: 'effective' speech and gestures such as promising, confessing, embracing, performed for others to interact with or witness. ${ }^{16}$ MT-3 stages the performance metaphors so frequently applied to ordinary life. While social dramas (Turner) can be represented by plays within, MT-2, they may figure as MT-3, where persons improvise parts in political conflict, as in T. S. Eliot's Murder in the Cathedral and Wole Soyinka's Death and the King's Horseman.

Since we all inhabit potentially conflicted roles, with more integrity or less; and since drama purports to represent us all; and since theatre and performance are 'in' the worlds drama mirrors, ${ }^{17}$ then with MT-3 we see the convergence of metatheatre with the theatrical generally. To be sure, this third category is vaguer. Perhaps to qualify as metatheatre, theatre-like moments from life must be made noticeable in the plot or text. Yet distinguishing 1,2, and 3 is not the point. The point is that the

11 See Gillespie 2019, on "showtime," referring to running time and time as experienced in a play/performance's world. Our Town ends at "Eleven o'clock in Grover's Corners," just when an eight o'clock three-act show would end.

12 Galileo, Brecht 1966, p. 55.

13 In his appreciation of Calderon's metatheatrical allegorical play, The Great Theatre of the World (1635), Hans Urs Von Balthasar 1988, pp. 19-20, 163-66, observes that God occupies all niches of the theatrical limit-of: author, director, audience (and in Christ the decisive, though invisible actor).

14 On performative selves, see Goffman 1959; Butler 1990; and also Bakhtin 1981, on hybridized social speech in the novel.

15 On theatre expressing pluralistic 'worlds,' see Quigley 1985. Of Yeats' play, The Countess Cathleen, Quigley writes, “The sense of remoteness and distance is one that is registered by the implied universality of the world motif. [. . .] We are invited to stand with Cathleen inside her world and contemplate from within the notion of its distant and remote horizons" (p. 9).

16 J. L. Austin's How to Do Things with Words (Austin 1962) is a text usually in the background of discussions of performativity.

17 On theatrical drama mirroring itself, see what Driver 1970, calls “theatrical positivism," pp. 348, 375-76. 
limits-to and limits-of personal and communal existence are disclosed and explored, delightfully and critically, 'at' and 'in' and 'through' the limits of theatrical drama. ${ }^{18}$

\section{Our Town and Our Towns}

The religious premises of Our Town are well known. In Act III, the Stage Manager asserts an alternative, interim temporality: the dead are "weaned" from finite attachments (confronting limit-to) to prepare for "something important," for "the eternal part in them to come out clear" (awaiting limit-of). Rather than sins being purged as in Dante's Purgatorio, it is life concerns, relations, ambitions, memories-and "your identity Mrs. Smith?" (p. 82). Identity is a radical thing to lose, but even in Paradiso mystical union with divine grace entails some relaxation from fraught earthly identity. Wilder's weaning temporality has its logic: before we can move on, we need release from what holds us back, especially if moving on entails a new discernment. Our Town is an intricately constructed play nearly ruined by jillions of cozy productions and the impression that a pale New England provincialism proposes Wilder's normative view of American society. ${ }^{19}$ To remain compelling, the play must show sources of disclosure and must apply levers of critique. My aim is to indicate where its forms of metatheatre and its religious premises intersect, seen in productions that resist the liabilities of nostalgia.

Behind a number of recent, edgy Our Towns is a Lincoln Center production of 1988, directed by Gregory Mosher (later broadcast on PBS, where I saw it) and remembered for Spalding Gray as the Stage Manager. The whole cast was stunning, particularly Eric Stoltz as George Gibbs and Penelope Ann Miller as Emily Webb, and it has been my reference point for the play. The staging was minimal as per the script, with period costumes except for Gray, who wore ordinary street clothes and spoke pointedly, without wizened crustiness. Detractors such as Frank Rich found him insufferable: Our Town can be dark but not that dark. Mel Gussow countered that though realistically dark, the show was not cynically dark. ${ }^{20}$ In my view, Gussow and Gray got it right. The cast resisted nostalgia to find aching ambiguity amid the compressed simplicities of home, society, and New Englandish intonations.

Today, good productions of Our Town are likely to look and sound like our towns, with vocal, social, racial, and gender inclusivity. In 2017, Deaf West doubled the roles with signing and speaking actors to convey the usual point that even in a "multicultural utopia," ${ }^{21}$ we should cherish every moment. I regret not seeing it, nor a startling production directed by David Cromer, which originated with Chicago's Hypocrites company. Cromer sometimes played the Stage Manager. He spoke as if 'out of character,' in the hurried but casual cadences of an office manager- "showing the new employees where the water cooler and bathrooms are"-in stage space closely crowding audience

18 My order of enumeration is merely convenient, from direct theatrical self-reflexivity to more indirect. If inspired by Paul Ricoeur's "threefold mimesis," I do not follow his order. It is possible my MT-3 corresponds to his mimesis-1, where human life always has a narrative quality that anticipates representation. My MT-1 (plays or performances that explicitly interpret themselves to audiences) may go with Ricoeur's mimesis-3, where we consciously interpret life in terms of narrative. Mimesis-2 is the narrative representation of life, as in fiction or history; it could include plays representing the performance of other plays, MT-2. See Ricoeur 1983, chp. 3.

19 Richard Goldstone's biography, 1975, pp. 140-43, treats Wilder's play as a normative celebration. Whereas I see its universals of value-in-the-mundane, associated with liberal America, serving as engines of critical resistance, here and in The Skin of Our Teeth (1942). Penelope Niven's Thornton Wilder: A Life (Niven 2012) gives a nuanced account of Our Town's making: he wrote Act III near Zurich (p. 442), while watching Europe and the world "rush into an abyss" (his words, p. 420). She finds a remarkable "amalgam of sources" immediate to the imagining of the play: "Ibsen and Nestroy, Dante and Molière, Gertrude Stein and Alfred North Whitehead" along with "Goethe, Balzac, and Nietzsche" (p. 426). Lincoln Konkle 2006, pp. 131-49, situates the play's idealized past and fraught historical present in the tradition of Puritan sermons and jeremiads.

20 Rich 1988; Gussow 1988. To be fair, Rich was decidedly mixed, praising the cast except for Gray, whom he thought incongruously repeated tones from his monologue and $1987 \mathrm{film}$, Swimming to Cambodia. But I find no "snide cynicism" in the 1989 PBS video, re-directed for television by Kirk Browning. Gussow noted that Gray "carefully avoids anything that might be misinterpreted as charm. At the same time, he is not dispassionate. He is, instead, realistic, as he explores the small pleasures and defeats in 'Our Town.'”

21 McNulty 2017, review of Deaf West's production of Our Town at the Pasadena Playhouse, Sheryl Kaller director (accessed 12 July 2019). 
space, the houselights always up; when Helen Hunt took over the part, she relished the incongruity of being called "Sir." 22 A danger in such universalizing approaches is that by eliminating $1901 \mathrm{New}$ England rural particularity, the universals may sound thin. Cromer countered with a chilling coup de théatre most reviewers at the time hesitated to spoil. In the third act, when Emily visits her past, the players donned turn-of-the-century attire. Then, more players than in the speaking cast brought in chairs to make for an uncomfortably packed graveyard. The audience found itself sitting among the uncounted dead. ${ }^{23}$

In what follows, I often have the 1988 show in mind, along with other productions. Since the Stage Manager's soliloquies are models for metatheatre- 1 , they may obscure -2 and -3 in the play; so, I will reverse the order here.

\subsection{Metatheatre-3}

In Our Town, metatheatre-3 provides a living performative background for rituals (metatheatre-2) like the wedding and funeral. By performative background, I mean social roles and parts routinely played (e.g., lover, soldier, physician, parent); effective speech and gestures (promising, giving); and audience-like, distanced witnessing of others' performances. On the morning of the wedding, Act II, Dr. and Mrs. Gibbs (Frank and Julia) are at breakfast, itself loosely a ritual. He mentions another ritual, having overheard George shaving and practicing " II do' to the mirror, but it don't sound too convincing to me" (p. 51). Frank then recalls their own wedding: "There I was in the Congregational Church marryin' a total stranger." His liminal fear back then was loss of words after a few weeks of conversation.

I was afraid we'd run out and eat our meals in silence, that's a fact. Well, you and I have been conversing for twenty years now without any noticeable barren spells.

MRS. GIBBS: Well,-good weather, bad weather-'tain't very choice, but I always find something to say. (p. 53)

Not only are the Gibbs describing ritual, they are critics of their performance. Catherine Bell argues that ritual's effectiveness depends on keeping its arbitrary, power-aggrandizing nature hidden, and Stephen Greenblatt believes staging ritual in theatre "empties" it of power by exposing its artifice. ${ }^{24}$ The Gibbs seem to register such worries—were the dialogue by Beckett, it might evoke absurdity—yet also refute them. Their ironizing routine talk at breakfast (artificial, different-yet-the-same) enlarges their and our sense of this breakfast ritual's import.

The Stage Manager then takes us back to the day the romance began. After arguing and reconciling at the drugstore soda fountain, where George decides not to go to agricultural school but farm in Grover's Corners and "improve" his character, George says to Emily, "So I guess this is an important talk we've been having" (p. 69). His statement observes their conversation like an audience, from a retrospective distance. The effect of this distance is to heighten their awareness of the talk's significance, a heightening the whole play attempts for its audience. ${ }^{25}$ To forgo college and school-smart independence to marry locally indicates the weight of social scripts. Played one way, it creates nostalgia; played differently, it could signal in Wilder a bourgeois complacency. ${ }^{26}$ Played yet another direction, the stereotypes are part of a critique that still honors simplicity. Wilder wrote Our Town with European democracy on the brink. By 1938, its pre-automobile, pre-radio, pre-women's

22 See Isherwood 2009, review of Our Town, Barrow St. Theatre production, David Cromer director; Patrick Healy 2010, reviewing Cromer's production now with Helen Hunt in the part of Stage Manager.

23 Shirley 2012, review of Our Town (with Hunt), at the Broad Stage in Pasadena, CA (accessed 12 July 2019 ).

24 Bell 1992, pp. 206-7; Greenblatt 1998, p. 126.

25 See Von Balthasar 1988, p. 83, on Wilder's "telescopic camera."

26 States 1985, pp. 97-99; Driver 1970, pp. 339-40. 
suffrage, pre-war, pre-Depression time was already a fading myth, imagined in an isolated 'corner' of New Hampshire. ${ }^{27}$ While Wilder shows via this mythos the unrecognized yet super-abundant value of ordinary moments—within "the Universe, the Mind of God" (p. 45)—-there are also critical impulses that good productions find.

Critique is noticeable in the portrayal of church choir director, organist, and suicide Simon Stimson. None will state what finally destroys him, other than alcohol. "Well, he's seen a peck of trouble, one thing after another..." trails off Mr. Webb, editor of the paper (p. 43). Was Simon gay and beside himself in marriage, depressive, trapped in debt, desperately bored, traumatized by culture? ${ }^{28}$ Indeed, 'culture' is another critique in Our Town. From the audience someone asks, "Is there no one in town aware of social injustice and industrial inequality?" And another, "Mr. Webb, is there any culture or love of beauty in Grover's Corners?" "Well, ma'am there ain't much-not in the sense that you mean." People attend to seasons, sunrises, and birds. They like Robinson Crusoe, the Bible, Handel, and Whistler's "Mother" (pp. 24,25). The Mind of (nature's) God and the blessed "ties that bind" encompass these matters of culture, history, and natural beauty. Yet the play knows our experience of this Mind to be ambiguous, as much of anguish as delight when trying to fathom life and death in its context. (The Stage Manager interrupts to say that paperboy Joe Crowell will study engineering and then die fighting in France, "All that education for nothing," p. 10).

\subsection{Metatheatre-2}

Our Town's ceremonies and rituals fit metatheatre-2 (plays within plays). There is the wedding, a choir rehearsal, and a hymn sung at Emily's funeral. More subtly in Act III, Emily observes her twelfth birthday, almost as if seeing a play. In plays or performances within plays, the outer play becomes the 'limit-of' dimension of the inner play. The limit-of the inner play can imply questions about limit dimensions of worlds for the audience. And when the inner performance (represented through the outer) is a ritual, where communication with transcendence is implied or expressed, then the limit-of implication may become explicit, as with the wedding.

"I play the minister." The Stage Manager's comments here are both metatheatre-1-he addresses us directly-and -2 , for they are a sermon at a wedding. "This is a good wedding, but people are so put together that even at a good wedding there's a lot of confusion way down deep in people's minds and we thought that ought to be in our play, too" (p. 71). Later, in Act III, he will say that "way down deep" we know of something "eternal." Here, the down deep is "confusion." He also speculates on the metaphysics of this "sacrament" (though in the terms of a Congregational modernist, not a Catholic) and tells us "the real hero of this scene" is nature.

It's like what one of those European fellas said: every child born into the world is nature's attempt to make a perfect human being. Well, we've seen nature pushing and contriving for some time now. We all know that nature's interested in quantity; but I think she's interested in quality, too,- - that's why I'm in ministry.

And don't forget all the other witnesses at this wedding, - the ancestors. Millions of them. Most of them set out to live two-by-two, also. Millions of them. (p. 71) $)^{29}$

If a kind of "interested" nature is the limit-of dimension (for the "perfecting" of human being), it is also the confusion we feel within, where eternity and value are found. What is more, this place at the edge of limit-of and limit-to includes "other witnesses," "the ancestors," an implied audience

27 See Goldstone 1975, p. 140

28 Of Jeff Weiss, playing Simon Stimson, Rich, 1998, wrote, "Mr. Weiss, a hollow-eyed and spindly figure in black, haunts Grover's Corners as if he were the repository of its citizens' smashed hopes and the lifelong victim of its mean, unspoken bigotry."

29 Konkle 2018, pp. 20-21, thinks the "European fella" is likely Bernard Shaw (preface to his play Misalliance). 
of "millions" that includes us. As Cromer's staging intuited, we also become positioned in the play's limit-of.

Our Town is aware that ritual constrains liminal confusion imperfectly. To be sure, the wedding frames its dangers comically, even patronizingly. George tells his mother he does not want to "grow old" and Emily asks her father, "Why can't I stay for a while just as I am? Let's go away" (p. 75). Mr. Webb defuses their panic just before the ceremony. When Mrs. Webb tells us (metatheatre-1) how "cruel" it is that mothers must abandon daughters, the stage direction recommends softening humor, "In half-amused exasperation" (p. 72). But only half; her next line may be played to devastating effect: "The whole world's wrong, that's what's the matter." Likewise, the Stage Manager's aside, "Do I believe in it? I don't know." He summarizes life, much as Jacques' speech in As You Like It. We go from "the cottage, the go-cart" all the way to "the deathbed, the reading of the will." Again, Wilder asks for a "smile," against any "cynicism" when the Stage Manager says of marriage, "Once in a thousand times it's interesting" (p. 78). ${ }^{30}$ However, at stake is not cynicism but tragic awareness, ${ }^{31}$ which struggles with Our Town's ontological vision of value and compassion in every moment.

During the wedding, the choir sings "Love Divine, All Loves Excelling" and "Bless Be the Tie That Binds" (also at the funeral). Both lyrics express earthly love recapitulating divine love, in "the fellowship of kindred minds." The script does not specify whether Simon Stimson leads the choir at the wedding; either way would be telling, contrasting his despair with the hymns or else implying he is already gone. In Act I, he rehearses "Art Thou Weary; Art Thou Languid?" and admonishes the choir, "It's a question, ladies and gentlemen, make it talk" (p. 35)—funny, unless it resonates with Simon's "peck of trouble." Dr. Gibbs tells Mrs. Gibbs, who saw Simon drunk at the rehearsal, "Some people aren't meant for small-town life" and "there's nothing we can do but just leave it alone" (p. 40). We next hear from Simon among the dead:

To move about in a cloud of ignorance [. . .]. To be always at the mercy of one self-centered passion or another. Now you know-that's the happy existence you wanted to go back to. Ignorance and blindness.

MRS. GIBBS: Spiritedly. That's not the whole truth and you know it. Emily, look at that star. I forget its name. (p. 101) $)^{32}$

Having died in childbirth nine years after the wedding, Emily returns to relive her twelfth birthday; she is a spectator, as if $a$ t and in a play. The Stage Manager had said, "You not only live it; but you watch yourself living it" (p. 91). Emily herself now sets the scene: "There's Main Street... why, that's Mr. Morgan's drugstore before he changed it! [ . . . . And, look, there's the old white fence" (p. 93, Wilder's italics). I will speak more to this, but in terms of metatheatre-2 and limit, Emily experiences a disjunction between limit-to (the finite edge of a domain) and limit-of (that is, 'beyond' the edge). Wilder's distancing wants us to see more intensely everything and everyone in the theatre space as being superabundantly meaningful or affecting. Theatrical distance is an analog for what Emily experiences upon her return to observe the living. Her impression is that the living do not see, as she now sees, which causes anguish-“Let's look at one another" (p. 99)—and is something to further explore. Yet Wilder lays in the subtle, metatheatre-3 implication that the living do sometimes see, especially when things are set off as if on a stage, even on minor occasions like birthdays.

30 According to Harrison 1983, p. 187, Wilder claimed he meant "interesting" as Gertrude Stein used it, apparently with light irony.

31 See Corrigan 1961, p. 171. In denying Wilder a "religious dimension" because he lacks consistent view of redemptive ultimacy, Corrigan may have imposed an either-or criterion of propositional coherence. In being variously Platonist, humanist, Christian, and tragic Wilder has an awareness of the fragmentary that Konkle 2018, calls postmodern. On the fragmentary, see also Tracy 1999, pp. 170-81.

32 From such passages and a comment by Wilder, McDonald 2018, presses the view that he portrayed human existence and the afterlife as "hellish," comparing Our Town with Sartre's No Exit," in Bryer 2018; this is probably "not the whole truth," however. 
EMILY: With an effort. Mama, I can't find my blue hair ribbon anywhere.

MRS. WEBB: Just open your eyes, dear, that's all. I laid it out for you special—on the dresser, there. If it were a snake it would bite you. (p. 95)

\subsection{Metatheatre-1 (Framing Metatheatre-2 and -3)}

Wilder did not find credible most English language theatre he saw in the 1920s. Consoling to an insecure middle class, it was theatre with surface verisimilitude but lacking the "real." Turn-of-the century drama smothered itself in "box sets" behind curtained prosceniums, and so became "a museum showcase" that "devitalized the theatre." 33 Yet one may reach reality through all sorts of theatre, from naturalism to symbolism to Brecht to the absurd. While Abel speaks of metatheatre aiming for life as dream, stage, and imagination in contrast to the real, he implies that the contrast is itself real, as are dreams and theatrical illusions. ${ }^{34}$ Moreover, a distorting funhouse mirror is still a mirror and can show us how we are. Here, I follow a distinction between naturalism-imitative of nature in acting style and scenography - and realism, a broader category for any dramatic mode that attempts to discern truthfully, even via oddity, surrealism, or farce. An ancient myth or avant-garde fantasy whose actions and motivations appear humanly plausible could have more realism than one without such plausibility.

In metatheatre-1, a play or performance pointedly refers to itself. It makes apparent its edge, with the audience situated just outside its expressive and material world, a participant, strangely, both in the world's 'beyond' (limit-of) and at its edge (limit-to). The Stage Manager is also outer and inner; he not only talks about Our Town but enters its world, taking parts as needed while serving us (and Emily) as a Virgilian guide to time out of time ("that element I merely took from Dante's Purgatory," Wilder wrote, xii). As he and other players directly acknowledge us, we help them define the play's boundary, at once definite, porous, and real. Whenever theatre-through living players, material objects, and stage space and time that overlaps our space and time-mirrors its own limits, it makes us participants in those limits. We, players and audience, lend our bodily materiality, emotions, and thoughts to the world-domain of the play and its edges. What was an abstract limit achieves concreteness via corporeality, perception, and expression, yet remains an abstraction. This much would be true of all drama, of great naturalism especially (Ibsen, Stanislavski). But Wilder's way of metatheatre-1 doubles-down on making the edge explicit, as the Stage Manager manages the bare stage.

No curtain. No scenery. [. . . ]

This is our doctor's house,-Doc Gibbs'. This is the back door.

Two arched trellises, covered with vines and flowers, are pushed out, one by each proscenium pillar.

There's some scenery for those who think they have to have scenery. (pp. 5,7)

By minimizing scenery, by insisting we think anew about scenery, and by intensifying our awareness of this or that person/actor, Wilder attempts to heighten our sense of material things that are also types or ideal things. This, I take it, is what his metatheatrical realism attempts: the 'merely' imaginary or illusory is realized by our 'being shown' the illusion's 'being made.' A few props, a defined space, and actual, intending persons all lend bodily credence to the imaginary. ${ }^{35}$ The unveiled illusion (which should remain an interesting illusion) becomes like a practical 'argument,' saying: this world

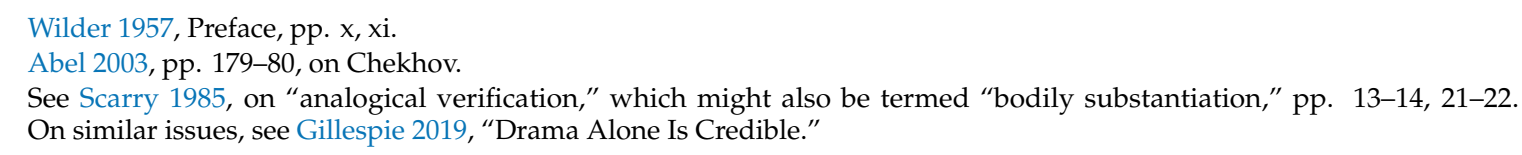


is plausible (perhaps real), not only because you have seen the making of it, but because you are participating in its making and its limits, at its edges and beyond.

Philosophically or theologically, the limit-of for Our Town would be the "something way down deep" that is confusing at the wedding and anguishing when Emily visits her past. The Stage Manager asserts (to us) near the beginning of Act III, "We all know that something is eternal [. . .]." The what is left unstated. Not houses, names, the earth, stars, or identity-yet "that something has to do with human beings. [. . . ] There's something way down deep that's eternal about every human being." At the cemetery, the dead-another 'audience,' in chairs facing us (or among us, in Cromer's staging)—are waiting and being patient (pp. 89,90), for what we are not told. They sit, losing interest in the past. The Stage Manager explains:

Gradually, gradually, they lose hold of the earth ... and the ambitions they had... and the pleasures they had... and the things they suffered ... and the people they loved.

They get weaned away from earth—-that's the way I put it—weaned away. (p. 81)

When Emily appears among the dead, she is already in temporal transition. "It seems thousands of years since I. . " “Oh, I wish I'd been here a long time. I don't like being new here" (p. 88). "Live people don't understand, do they? [ . . ] I feel as though I knew them last a thousand years ago [. . . .] Mother Gibbs, when does this feeling go away?-Of being... one of them?" (pp. 89,90). Emily is becoming distant yet also still attached to the living- "Mother Gibbs, George and I have made that farm into just the best place you ever saw. [ . . . .] My boy is spending the day at Mrs. Carter's" (pp. 88, 89)—and realizes she can visit her past. The dead and the Stage Manager warn against it: "you see the thing that they-down there-never see. You see the future. You know what is going to happen afterwards" (pp. 91, 92). In her in-between state, her seeing will be finite, like our seeing, but from a vantage point nigh eternity unavailable to the living-except as we share her place, now, with the ancestors.

Mrs. Gibbs says that visiting the past is not pertinent to the dead, who are "to forget all that, and think only of what's ahead" (p. 92), which is never revealed. Yet effective productions create the impression something has been revealed, partly depending on what we can read into it: Paradise? Judgment? Fulfilling insight? Harmony or love? Wilder suggests that the eternal way-down-deep is a superabundance of "value" (xii) immanent in the quotidian moment. Yet this "wonderful" nexus of value and meaning is so distant to ordinary sight that to perceive it retrospectively prompts anguish akin to grief. Wonder becoming anguish is what Emily feels when she returns and sees. "I can't look at everything hard enough" (p. 97). "I can't go on. It goes so fast. We don't have time to look at one another. [. . . I I didn't realize" (p. 100). Such lines risk sentimentality yet express anguished insight. Penelope Miller found a near perfect balance in the potentially maudlin but luminously devastating farewell, "Good-by Grover's Corners": "Oh, earth, you're too wonderful for anyone to realize you. [. . .] Do any human beings ever realize life while they live it?-every, every minute" (p. 100).

We in the audience are to undergo an apophatic or via negativa discernment like Emily's. We, for a moment, are to see with her. We are to see the invisible by seeing how the living do not see. She and we see the whole of persons' lives-in-time (a limit-to dimension) in individual moments of their lives. This intense perception is not just knowing "what's going to happen afterwards" (p. 92), though is partly that. It is also the effect of temporal and spatial layering: particular past moments seen in light of other past and future moments which, sub specie aeternitatis, are already part of the nexus of meaning. The living see only a little of this polyvalent nexus. Emily discerns it via contrast with the living and supposes them willfully blind. "Oh, Mama, just look at me one minute as though you really saw me" (p. 99). It is not that she sees everything or they nothing. The living do see-“open your eyes"-and the weaning dead see much more but remain limited, as when Mrs. Gibbs rebukes Stimson: "that ain't the whole truth." We now are in a similar predicament as Emily, seeing more of the very much more. The anguish is not exactly grief, if grief entails decathexis, or loss of connectedness. The pain, rather, comes of reconnection, via extraordinary discernment that is more than finite spirits can withstand, except "the 
saints and poets, maybe" (p. 100). A question remaining is why the dead should be "weaned" from the content of this pain. I shall consider that, after comments on other productions that have enhanced this discernment.

Effective realizations of Our Town must be compelling, in respect both to the via negativa mode of discernment and the play's polyvalent disclosures of value, time, and eternity. Lori Ann Laster reports on bunraku puppets, vocalized by actors to stylize and distance the townspeople and which are later sprawled lifeless at the cemetery, "corporeal symbols for the hopeful spirit that swiftly dwindles when one passes over into death." Another company staged Act I as a 'table read' rehearsal led by the Stage Manager, until the moment he turned and explained to the audience that the Grover's Corners bank will deposit Our Town in its time capsule. "By breaking the fourth wall here rather than at the beginning of the play, Amster [the director] made the trope of direct address powerful and immediate." ${ }^{36}$ Laster also comments on a 2007 production at Connecticut's Hartford Stage, which brought back veteran Stage Manager Hal Holbrook, then 82, who captured "the play's occasionally dry melancholy." All his words about mortality_- "you make some decisions; then whissh! You're seventy" (p. 60)—reflected back on him, no matter how understated. His age was layered over the timeless part. Ben Brantley wrote similarly of Paul Newman, 77, in the 2002 Westport (Connecticut) Country Playhouse production. Again, memories of a long film career overlaid his wry, rumpled Stage Manager, who seemed to be "inventing his lines on the spot," without the direr ironies of Spalding Gray. ${ }^{37}$

Timelessness cannot directly be represented by finite, temporal art. A very old Stage Manager can do so indirectly: the more years, the more timelessness. However, in 2002, the Transport Group did Our Town in New York, which I saw. Director Jack Cummings III cast against age: George and Emily (Tom Ligon and Barbara Andres) were in their sixties, with a Stage Manager played by Emma Orelove, age 12. Music and a prologue were added, of quotable lines from the play's wisdom; lighting effects and projections created a cool, autumnal, abstract space. The play kept to Wilder's minimalism, so the major innovation was the actors' ages.

From reviews, my guess is that old George and Emily were better received than the child Stage Manager. Anita Gates saw George and Emily much as I remember, having "within them the middle-aged couple they're destined to be, as if the gray-haired adults can fulfill the dream of being with their parents in their youth and vigor again but knowing what they know now." ${ }^{38}$ Not only do we see them as they might have become but, more subtly, we see two superimposed lifelines, as if both had reality. Simultaneity of this sort may or may not have been anything Wilder anticipated. Even so, given how he played with Augustine's and Dante's views of the presence of eternity to past, present, and future, juxtaposed with a modern picture of the future as unrealized possibilities, a 'real' simultaneity may be implied in his vision of superabundant value in the unseen eternal. ${ }^{39}$ Some thought Orelove could not credibly deliver the crusty nuances of a Gray or Holbrook, but this was to miss the point. Rather than speaking from worldly wisdom, she spoke from ageless simplicity. Or so was my impression, and I still find her interpretation valuable. Yet this is a time to take up a question hinted earlier about Wilder's vision of near infinite value layered in every moment.

Why would it be good for the dead to be weaned from meaningful, albeit earthly attachments: ambitions, pleasures, "the things they suffered... and the people they loved"? Why should they become "indifferent" as they wait "for the eternal part of them to come out clear?" Because of the anguish of such knowledge? (Best to "forget all that," says Mrs. Gibbs, among the dead.) Because a

36 Laster 2008, highlighting 2007 productions by the Two River Theatre Company of Red Bank, New Jersey (directed by Aaron Posner-with puppets); the Indiana Repertory Theatre of Indianapolis (directed by Peter Amster-as if a table reading); and the Hartford Stage (directed by Gregory Boyd—with Holbrook).

37 Brantley 2002, review of Our Town as directed by Mark Lamos.

38 Gates 2002, review of the Transport Group production of Our Town, directed by Jack Cummings III.

39 Konkle 2018, p. 21, notes the Stage Manager is simultaneous to all times in the play, 1899-1913 (and 1938 and the date of any performance). Temporal simultaneity is not just biblical-medieval but reappears as a poststructuralist view of semiosis synchronically levels discourse into the intertextual all-in-all. See Mark C. Taylor 2004, "Betraying Altizer." 
fuller perspective on the past would distract from preparing for "what's ahead"? Moreover, should not the Stage Manager know what is ahead? He should, if we take him to be a God-figure. ${ }^{40}$ There may be aporias here, forgivable given the impossibility of answering such questions; Wilder may have been simply (or way-down-deeply) inconsistent.

However, Wilder's reference to Purgatorio leads me to think the Stage Manager is more a Virgil-figure, who in Dante knows that there is redemption but has only a vague notion of what redemption is. The analogy breaks down, of course, for the Stage Manager is among the living ("we're coming up here ourselves when our fit's over," p. 81), and Wilder suppresses references to Christian atonement except in the hymns. Our Town is a better play, however, if the Stage Manager, like Dante's Virgil, knows a lot but not everything, with more of a grasp of limit-to than limit-of. He may not know for what clarity the dead await, nor whether "weaning" is the best metaphor for their waiting. Might he be just a bit of an unreliable narrator? In any case, old men with silver hair are reminiscent of a folk picture of God Wilder would never endorse. Whereas, a red-haired twelve-year-old evokes no such cozy familiarity and might for that reason be a very appropriate guide.

\section{Sundays in the Park}

If there are God figures in Sondheim and Lapine's Sunday in the Park with George, they are not the artists who make aesthetic worlds, but "Sunday," the song that soars from the tableau-vivant of Seurat's painting before each act ends. ${ }^{41}$ There is, however, a Beatrice-figure, Dot, who answers a limit question left begging by Emily and the Stage Manager: why should the dead be "weaned" from what the living do not really see? Her answer to George and George, from a theatre-magic place at once present to past and future, is simply that we, the living, do . . . see. Dot sings, "Give us more to see ..." (p. 198). She invites us into such a place of participatory discernment.

Although conventional God figures can allegorize conceptions of limit-of (the 'beyond' of a horizon of discourse and experience), as conceptions they are arguably limit-to. A conception of the divine or ultimate may, at the level of experience, imply a question of boundary without participating in a movement of mind and feeling beyond it, as a symbolic, aesthetic, or ritual process might. Are there religious premises and questions in Sunday in the Park analogous to Our Town's? There are no sacred hymns, rituals, sermons, or prayers. Implied weddings and funerals occur outside the scenario (though testimonials to Seurat in Act II are like eulogies), and there are few religious words (a reference to "Ascension Day 1884," when Seurat began the painting). Even so, Sunday in the Park evokes limit structures related to creation and revelation and to discernments that transcend time. So, when the 1884 Dot appears to the 1984 American artist George on an island in the Seine, she is also appearing to her lover, Georges Seurat (died, age 31). Speaking and singing with Dot (whose old grammar book he carries), the postmodern George is also conversing with his grandmother Marie, Dot's daughter, who kept the book and has just died, at 98. When he ritually reads Seurat's words of transcendental efficacy, much like Platonic aesthetic forms-Order, Design, Tension, Composition, Balance, Light, Harmony, which Dot copied in the book-it is as if Seurat, Dot, Marie, and George become simultaneous. First played by Mandy Patinkin and Bernadette Peters, they sing of "parasols" and "People strolling through the trees/[. . .] On an ordinary Sunday" (pp. 201, 202). ${ }^{42}$

Up to this point of intergenerational hyper-connectivity, Act II has been problematic. It competes with the amazing set pieces of Act I, where Neo-Impressionist masterpieces come to life, principally Seurat's Sunday Afternoon on la Grand Jatte (1884-1886), also Bathers at Ausnières (1884) and Young

40 As does Von Balthasar 1988, pp. 351-52, and Konkle 2006, p. 142.

41 The artists are the fictionalized Georges Seurat (1859-1891) and his entirely fictional great grandson, George, in 1984 (the year the completed musical opened; Act I was performed in 1983). No character in Act I refers to "Seurat," always "George," but to avoid confusion I usually refer to this character as Seurat.

42 PBS broadcast this production on American Playhouse in 1985. I am indebted to comments from Austin Bouchard, whom I saw play George at the University of Mary Washington in 2014, directed by Gregg Stull. 
Woman Powdering Herself (1888-90). Act II also competes with stories imagined from figures in the painting: earthy and finer folk, some at odds with each other and Seurat, who studies and corrals them into his composition. What Dot calls his "mission to see" (p. 109)—-theorized as pointillism and chromoluminarism - is in conflict and contiguity with his inarticulate feelings for her-mistress, model, and unacknowledged muse. By contrast, the George of Act II is an electronic sculptor-inventor whose Chromolume series would fulfill, he hopes, Seurat's dream "to paint with beams of colored light" (p. 147)

Any production of Sunday in the Park must deal with how Chromolume \#7, though important to George and indeed intriguing, is not clearly compelling as an artistic "invention." On one hand, everyone except Marie doubts it, including eventually George himself. Should productions make the device better than it is, or bring it 'up to date' with electronics unavailable in 1984, they risk overshadowing the final, theatrically simple appearance of Dot, or else contradicting "Putting It Together," a number that while cynical makes some astute judgments. Recall that Seurat had employed materials, paint and brushes, used for centuries. Whereas whatever gadgets George uses, be it lasers or "a new state-of-the-art Japanese microcomputer which controls the voltage regulator" (p. 149), a Chromolume will date itself the day it switches on. The electronic music accompanying it, and briefly shorting it out, may also date it. And while Act I imagines a variety of near archetypal figures-mistress, elegant artist, rough boatman, soldiers, animals, baker, fisher girls, mothers, nurse, dandy, children ${ }^{4}$ - George in Act II must hobnob with dubious brokers from the modern art racket.

On the other hand, we must not miss George's serious intent with the Chromolume, not only for his life and art but also for thematic connections to Seurat. A 2017 New York revival, directed by Sarna Lapine (James' niece), approximated pointillism by trading laser beams for firefly patterns from many small, suspended lights rising, falling, and changing color above the audience. ${ }^{44}$ We learn in Act II that Seurat lived only a few more years, leaving us to imagine his work, had he lived, overlapping Kandinsky, Braque, Mondrian, and Picasso. We may glimpse in Act II's George, then-as with the older Emily and George in the Transport Group's Our Town - unrealized possibilities and limit dimensions of Seurat's life, art, and love. Sarna Lapine also believed "the piece itself was about transcending time." ${ }^{45}$

When Sunday in the Park moved from Playwrights Horizons to Broadway's Booth Theater in 1984, directed by James Lapine, its design was quite literal. There were flying and sliding flats approximating the park-painted trees, water, grass, sky, later the modern buildings-and life-size cutouts of figures not enacted, including two dogs, a monkey, and the Soldier's Companion. In Act II George, bored with guests at the museum reception (the same actors from the painting in Act I), "raises up" photographic cutouts of himself for them to talk to, which added jaded fun to an already satiric scene. (The cutouts are specified in the published text.) The 2017 revival evolved from a 2016 concert production at New York City Center with Jake Gyllenhaal as the two Georges and Annaleigh Ashford as Dot and Marie. Of the full production at the Hudson Theater, Sarna Lapine describes decisions to remain minimalist with a small playing area. The scrim with projected impressions of the painting also allowed audiences to see the orchestra; the effect suggested a canvas in a park for some simple performance. Gone were the cutouts (except for the dogs). Acting choices also made for a more integrated story, in respect to the character links and contrasts between the acts. With such possibilities in view, let us see how metatheatre configures 'limits' in Sunday in the Park with George.

43 On the painting's history of interpretation, many coalescing around class differences, see Herbert and Harris 2004, pp. 152-69. Had it come earlier, Herbert's own interpretation, pp. 170-75, of "fashion and irony" in the painting could have informed the play's metatheatricality.

44 I am unsure of this device, though some liked it; see Brantley 2017, reviewing the Sarna Lapine directed revival. On a YouTube video of the whole show, shot obliquely from the audience, the effect seems disconnected from the production's otherwise intimate staging; it did provoke an enthusiastic reaction.

45 Myers 2017, interviewing Sarna Lapine (accessed 31 July 2019). The Interval stopped publishing on June 20, 2019. I will keep available this interview for anyone interested. 


\subsection{Metatheatre-1}

Although both Seurat and George manage stages (Seurat poses people and shows his work to Jules, a rival artist; George publicly introduces his Chromolume and cajoles patrons at the reception), neither directly breaks the fourth wall like Wilder's Stage Manager (though they may carry scenery such as cut-outs). The two Georges remain in their fictive worlds, except for the play's first lines, where Seurat is in lecture mode: "White. A blank page or canvas. The challenge: bring order to the whole" (p. 21). Then he intones a litany of aesthetic principles-from design to light and harmony-and with each word, the park's trees, sky, landscape, and water appear. A perennial conundrum in aesthetic epistemology is whether artists find new worlds or create them, or find them through creation. Are Seurat's aesthetic principles eternal forms beyond the mind or Kantian a priori that live within? The question goes to Tracy's distinguishing limit-of from limit-to- that is, the inferred ontological ultimate from the experienced, ontic boundary. Sunday in the Park will not resolve this question but keeps returning to it as it articulates and crosses metatheatrical edges and limits.

Musicals break the wall with their 'numbers,' listed by title and character in the program. Even when integrated with the plot, numbers can be showstoppers, necessarily sung to $u$ as well as to other characters. Numbers are as much commentary as story, establishing themes and ranges of emotion. As if to say to us, "We are at a musical" and indeed we are in it, for our applause affects the show's momentum. All this is true in Sondheim: people burst into song and tell you how they feel and what is going on. Yet the boundaries of his numbers are harder to demarcate, especially on the printed page where, in Sunday in the Park, they read smoothly together with the unsung dialogue. ${ }^{46}$ In this way, Sondheim's numbers are like Wilder's Stage Manager, who talks to us and to various characters.

Dot, however, frequently does speak retrospectively to us in Act I, and so is more a metatheatre-1 presence than Seurat. Her first number, "Sunday in the Park with George," comments on the world the song establishes and values: "there are worse things" than posing in the summer for your artist-lover "On an island in the river on a Sunday" (p. 30). By the first act's end, her appreciative complaint has become "Sunday," hymn-like in emotion and which articulates Seurat's method of color juxtaposition. Colors mix not on the canvas but "in the eye." And despite the stasis of these figures 'living' forever in a painting, the song suggests liminal passage toward a verticality within but not of the limits of 'ordinary' time. ${ }^{47}$

Sunday,/By the blue/Purple yellow red water

On the green/Purple yellow red grass,

Let us pass through our perfect park [. . .],

Through arrangements of shadows

Toward the verticals of trees/Forever...

[....]

On an ordinary Sunday ... (pp. 127, 128)

Then, at the play's finale, before the stage becomes a blank canvas and George says, "So many possibilities," "Sunday" reprises as he reads Dot's note in the grammar book about her George, "So much love in his words ... forever with his colors ... how George looks ... he can look forever ... what does he see?" (p. 201). "Sunday" frames the simultaneity Dot and the two Georges share with each other and with Marie. And the song frames us in the limit dimensions of the play, 'beyond,' 'at,' and 'within' its world (especially if we happen to be enjoying a Sunday matinee).

46 See Sondheim 2011, Look, I Made a Hat, pp. 6, 17.

47 The play's Sundays are during summer. Gillespie and I wonder if Sondheim and Lapine were alert to the Christian liturgical meaning of 'ordinary time' after Pentecost in the spring. 


\subsection{Metatheatre-2}

To witness art within art or plays within plays can be analogous to revelation. To stage a drama within a drama can be an analog to creation, as when Hamlet penned a new version of The Murder of Gonzago. Yet the limit, there, is more about creation's limit-to than limit-of. Hamlet plays not God but detective; he contrives a theatre-place in which to observe what none can see, the within of another mind. He intends his murder-mystery to prompt Claudius to reveal himself, yet there are reasons to think Hamlet only sees what he expects to see. Claudius remains opaque a while longer. If there is a limit-of dimension in Hamlet's playing within and without, that dimension is rather literally us. With Hamlet we see Claudius apparently at prayer, but only we hear what weighs upon his conscience. We are positioned in Hamlet's limit-of, in its regions beyond, as if participating in a divine or Shakespearean judgment-at least until judgment turns back upon us, finding us again within the play, with Claudius and Hamlet. Yet surely the art within art in Sunday in the Park is not of anything so morally fraught as murder.

The story goes that Sondheim, discouraged by the flop of Merrily We Roll Along (1981) and swearing off theatre, met playwright Lapine and discovered they shared an interest in Seurat. Sunday in the Park was in effect born of conversations before a painting. ${ }^{48}$ As Sondheim wrote the songs and score, he imagined Act II as theme and variations on Act I, but Lapine knew it would require a connected story. Thus, the invention of a great-grandson who makes conceptual art a century later and only half-believes his grandmother is the bundled-up baby in Grand Jatte. So, the musical was conceived both as a painting within a play and a play within a painting. The painting, moreover, is 'in' images the script indicates are projected by the Chromolume, whose principles of light derive from principles in the painting.

In Act I, analogs to plays within plays come when art is performed, chiefly by Seurat. He poses, draws, and paints Dot and the quarrelsome folk who frequent the park on Sundays, including his mother (who pretends not to recognize him!) and two dogs whose doggy conversation he mimics in "Day Off." His most important performances are with Dot, whom he teaches to "concentrate," and in the studio as he demonstrates pointillism. Act II begins with a tableau-vivant within a play; the figures in the painting, itchy in an eternal now, complain, "It's Hot Up Here." "Putting It Together" also has metatheatre-2 characteristics but will better serve the discussion of meta-3.)

Dot finds posing torturous and thinks concentration is merely "the art of being still" (p. 46) while being arranged like an "object" (p. 30). A moment of metatheatre-2 involves the actor, originally Peters, stepping out of her rigid dress to strike sexy modeling poses. (In 2017, Ashford played it without the costume-prop effect and with more seductive affection for Seurat.) Dot imagines herself in the Follies as she applies powder and makeup—-more rouge"-much as he paints-"more red" (pp. 48-50). Yet when Dot reappears in Act II, she has learned that concentration is a form of discernment akin, I take it, to today's 'mindfulness' or more ancient practices of contemplation. She tells George (i.e., Seurat and her great-grandson) that he gave her "concentration."

At first I thought that meant just being still, but I was to understand it meant much more.

You meant to tell me where I was-not some place in the past or future. I worried too much about tomorrow. I thought the world could be perfect. I was wrong. (p. 194)

We could postpone Seurat's theory of color for metatheatre-3 (the drama-theatrical, artful facets of ordinary life), but since we see him painting and explaining his painting, metatheatre-2 fits. In "Color and Light" Seurat, intermittently aware of Dot whom he loves and emotionally neglects, applies points of paint to an unfinished Grand Jatte:

48 Secrest 1998, pp. 326-28. Zadan 1986, p. 308, reports that Patinkin in preparation spent hours with the painting at the Art Institute of Chicago. 
There's only color and light./Yellow and white.

Just blue and yellow and white.

(Addressing the woman he is painting)

Look at that air, Miss. [. . . .] That's done with green ...

(Swirling a brush in the orange cup.)

Conjoined with orange. (p. 48)

Pointillism and chromoluminarism should be distinguished, though the play mentions neither term. ${ }^{49}$ Seurat's pointillism used dots or tiny daubs of paint without blending them on the canvas. To suggest this, Patinkin in 1984 stood facing the audience while behind a transparent scrim (with the unfinished painting projected on it) as notes matched his staccato brush strokes. Gyllenhaal, in 2017's staging, simply faces us as he paints, which would more emphatically position us in the painting's world of dots. If so, we 'are' both among those whom Seurat is painting-figures in Grand Jatte-and witnesses to his creating. And since in live theatre the audience is among the performance's creators (for we lend it our perceptive attention, without which it is not) a collaborative relation is obtained: we 'paint' Seurat, as Seurat paints us. What makes our participation in the play's limits more than an enjoyable curiosity are questions of responsibility to and for art, and to and for persons, in the present and over time, which the painting and play raise in miniature and at large. In miniature, these questions arise with chromoluminarism.

Chromoluminarism is a technique of juxtaposition. Particles of adjacent, different colors create the shimmer of a third. Seurat asks Jules about a flower on a hat, "What is the dominant color?" Violet, but look closer and one sees dots of red and blue. "So?" "So, your eye is perceiving both red and blue and violet. Only eleven colors-no black—divided, not mixed on the palette, mixed in the eye. Can't you see the shimmering?" Apparently not, "You are a painter, George, not a scientist!" (p. 103). George and Marie in Act II also explain:

Having studied scientific findings on color, he developed a new style of painting. He found [. . .] that at a certain distance the eye would fuse the specks optically, giving them greater intensity than any mixed pigments.

MARIE: He wanted to paint with colored lights.

GEORGE: Beams of colored light, he hoped. (p. 147) ${ }^{50}$

The conception is not only a matter of color consciousness. Juxtaposition creates space for worlds to emerge at the boundaries or in the gaps between what is juxtaposed-whether it be simply a world of color or a rich, thematic world. Such is the point of "Finishing the Hat," where the art story and the lovers' story cross. Dot leaves Seurat, who did not take her to the Follies because that evening, as on other evenings, he had to "finish the hat." She has left him for an emotionally more reliable "artist," Louis the baker ("he kneads me/I mean like dough, George," p. 95), who marries her though she is pregnant by Seurat. He is also rejected by the jealous Jules. Seurat's painting can be understood as an expression as much as impression, for when light comes together- "dot by dot"—a world emerges with the object. "Coming from the hat,/Studying the hat," you are

49 Chromoluminarism was Seurat's term, changed to divisionism by Paul Signac. See Jane Block, "Pointillism," Oxford Art Online/Grove Art Online, (Block 2003), https://doi.org/10.1093/gao/9781884446054.article.T068278 (accessed July 30, 2019). Grand Jatte did not begin as pointillist; Seurat introduced dots and tiny marks in later phases (Herbert and Harris 2004, p. 111).

50 Herbert 1968, pp. 18-20, rejects the movement's claim that colors optically and objectively mix 'in the eye' at given distances but affirms the shimmering effect for the viewer. The play's violet example is a little misleading, for the colors Seurat juxtaposes need not be primaries. 
Entering the world of the hat,

Reaching through the world of the hat

Like a window,/Back to this one from that.

"Like a window" can associate with religious icons, often described as transparent to the spiritual realities they represent. And this window seems a two-way passage to objects and to persons.

Studying a face,/Stepping back to look at a face

Leaves a little space in the way like a window,

But to see-/It's the only way to see. (p. 94)

Do these faces precede the artist, to be encountered like living Platonic forms, or do they proceed from Seurat's ways of composing and juxtaposing worlds? Well, it's ambiguous. He shows a sketch to Fifi, a yappy dog in the park: "Look, I made a hat.../Where there never was a hat" (p. 95). He tells Dot that while caring "about many things" and "People too," he is "not hiding behind my canvas-I am living in it" (p. 107). Dots of color set beside other dots, and persons in arrangements with other persons create spaces for life. That what he tells Dot rationalizes his neglect need not diminish its possible truth. In "All Things Are Beautiful," when his mother fears losing the view from the park to developers clearing space for the Eiffel tower, he explains, "I'll draw us now before we fade, Mother [. . . . ] You watch/While I revise the world" (p. 113). Yet the song leaves open what Tracy might view as the limit question of whether artists make, or revise, or discover a beauty transcendent to the artist's purposes in the world.

Jules is of the opinion, later retracted, that Seurat's work has "No Life," is "density/Without intensity," and "mechanical" (p. 39). These criticisms ignore enigmas in the painting, the couples and solitary persons whose stories beg to be imagined: who are they, how are they so calm, why are they here? The mechanistic critique is literalized in Act II, for George demonstrates a machine, provoking some guests to say that if his Chromolumes were ever new, they are not new now. The critique is framed by the meta-critique of "Putting It Together," which cleverly treats artistic collaboration as money-chasing expediency. This number is fun and cynical ("Every time I start to feel defensive,/I remember lasers are expensive," p. 166) and introduces tensions, even contradictions that Sunday in the Park strains to make productive.

\subsection{Metatheatre-3}

An implication of chromoluminarism is that color and retina cooperate, or that nature and spirit are mutually implicated—one of the "Romantic principles" (p. 145) George says Seurat superseded through "scientific" understandings of color and light. However, that the mind brings to proximity red and blue (nature) to make and reveal violet, and that the violet discloses value and meaning (spirit) remain broadly Romanticist ideas though classically staged (in Grand Jatte's ancient Egyptian stillness and harmony). A corollary would be that violet emerges from a collaborative performance between blue and red, and between artist and viewer. ${ }^{51}$

So, if the cynicism of "Putting It Together" implicitly assumes that authentic art could only arise from individual, untainted genius—and thus doesn't really arise at all—then it undercuts the play's premise, namely that art and life, at once internal and external to one another, cannot happen alone but are inherently collaborative. The jaded spirit of this long number (about eleven minutes) may pander to an antitheatrical nostalgia for a 'being not seeming' it knows it can never have. Art generally and theatre especially requires people, money, and criticism; "Putting It Together" knows this but risks casting it as a slur. The "antitheatrical prejudice" is part of an anti-aesthetic bias that would 
favor purity, authenticity, and sincerity. Inasmuch as forms of these biases occur throughout cultures, notably when they comment on their arts, it is crucial that art and theatre explore and revise these prejudices and pre-understandings. ${ }^{52}$

The stories in Act I masterfully show this exploration. Does art disclose common life or cover it over? Does it distance us from the real or find the right distance to see? When the one-eyed Boatman calls "hypocrites" the upper crust people visiting the park, the kind who pay for fine paintings, he repeats an ancient trope. (In Greek, the term was idiomatic for actors.) Yet for a moment, he finds common spirit with Seurat. "You and me, pal,/We're the loonies [. . . . ] 'Cause we tell them the truth [. . . .]You and me, pal,/We're society's fault. (pp. 82, 83). Whereas the German coachman Franz doubts artists really work. "Artists work," his wife Frieda counters, "I believe they work very hard." "Work is what you do for others," Franz sings, "Art is what you do for yourself" (p. 79). Nearly all the Act I characters comment on art, class, and their tasks and status in life. The point is that Seurat (the musical painter) succeeds in bringing them into uncomfortable yet ecstatic collaboration, as they sing "Sunday" and take us to and beyond the temporal and spatial limits of ourselves.

By contrast, the cross section of George's acquaintances at the Act II reception is rather narrow; in one fashion or another, they are from the art-business world. Act II is less of the art than the artist, and about whether George can overcome disconnectedness in his circle of relations. The "state of the art" partygoers patter on about the "new" and trivialize it. They even trivialize Seurat: "the painting's overrated" (p. 177). Yet a few make valid points, especially George's technician Dennis and the art critic Blair Daniels (played the actor playing Seurat's mother). "You were really on to something with these light machines-once. Now they're just becoming more and more about less and less." A danger is that her judgment, if not played with nuance, will also apply to this section of Sunday in the Park. ${ }^{53}$

In the 1984 production, George sang over Blair's sentence and set up another cutout of himself for her to criticize: "Not that you couldn't succeed by doing Chromolume after Chromolume-but there are new discoveries to be made, George" (pp. 174, 175). ${ }^{54}$ The parody may deflect validity from her critique. However, in 2017, Sarna Lapine spent much time developing character links between the acts, including Marie and Dot—as muses to the two Georges—and between Blair and the idea of "mother as first critic." ${ }^{\prime 5}$ Dispensing with cutouts, the players merely froze in place during George's asides in "Putting It Together," but Blair (Penny Fuller) did not freeze, so her perspective came through. She softened the satire yet deepened it, giving it personal and felt validity. Dennis and Dot will speak similarly. Dennis has decided the Chromolume on the island will be his last. He knows George is repeating himself and George knows too: "I just want to do something I care about" (p. 190).

Of those at the museum reception, only Marie has unqualified praise for her grandson's Chromolume. Fatigued from the presentation and seeing that George is "blue," she discerns value in his creation. From her wheelchair, she turns to Seurat's La Grand Jatte, which hangs near them, and sings as if to her mother.

I don't understand what it was,

But, Mama, the things that he does-

52 On common prejudices against theatricality, see Barish 1981. On the positive significance of "prejudice" and revision in understanding, see Gadamer 1989, pp. 265-71.

53 McLaughlin 2016, pp. 160, 166, implies that despite their sophistication, the partygoers share with Seurat's critics a naive bias, namely that for art to be authentic it must correspond to privileged reality. If so, their portrayal of art as merely an illusory power game contradicts their incipiently realist assumptions. They cannot reconcile how it is through artifices and social collaborations that art—and theatre—can "revise the world" and make it "beautiful" (as Seurat says in "Beautiful"). They are antagonists to the art trends they chase and as unable to see as Jules was unable to see La Grand Jatte. My worry is that if Sunday invites us to be too cynical about these cynics, it may inadvertently join their cynicism and short circuit (like the Chromolume).

54 In a 2005/2008 London/New York revival directed by Sam Buntrock, which used digital animation for paintings and scenery, the cutouts became video projections of George (played by Daniel Evans). "With all these "multiple George-representations seeming as real as George, it is no wonder he becomes confused" (McLaughlin 2016, p. 164).

55 Myers 2017, interview with Sarna Lapine. 
They twinkle and shimmer and buzz-

You would have liked them .../It .../Him ... (p. 184)

Marie (like Dot) is a muse of relationality who connects the new of the now with "Children and Art." ('You know, it is all you really have," p. 181.) She sees her mother in all the painting's people. "Mama is everywhere,/He must have loved her so much ..." (p. 185). "See how she shimmers-/I mean from the heart" (p. 186) As did Wilder, Lapine and Sondheim juxtapose daily relationships with the artistic and natural sublime-and with the theatrical sublime, if we regard both Sunday in the Park and Our Town as making the commonplace disturbing or astonishing. Just as Wilder risks pathos with Emily's "Goodbye Grover's Corners," Sondheim risks cliché with "Move On," but allows music and voice, with emotion and intelligence, to lift truism into insight.

DOT: Stop worrying if your vision/Is new,

Let others make that decision—/They usually do./Move on. (p. 197)

George, despairing of his vocation and missing personal "connection," goes to the island in Paris with Dennis to present one last Chromolume. Marie was to have come too but has died. Dot, dressed as in the painting, appears and thanks George qua Seurat for what he "gave" her and asks, "Are you working on anything new?"- the old query but here asked with love. She knows striving for the new risks contradicting ordinary beauty and light. To my eye, "Look at what you've done/Then at what you want,/Not at where you are,/What you'll be" (p. 197) makes only a little semantic sense. Is not "where you are" something to be discerned, attentively? Yet the dialectic of the new and the ordinary is resolved and exceeded by Dot's "Anything you do/Let it come from you./Then it will be new./Give us more to see" (p. 198).

Recall the question left by Wilder: why should the liminal dead be weaned from associations, memories, and relations layered in each moment, which in life we cannot really see? Well, we are finite. Superabundant possibilities, which in all relationships are real yet unrealized, would be anguishing to see at the limit betwixt time and eternity. Sondheim and Lapine answer that we the living can and do "see." In transformed moments, we discern the flecks of light, sound, and meaning, here approximated by music, lyric, stage, and the story's superimposition of Seurat, Dot, and Marie with George. These graced times of seeing together return us to the metatheatre- 3 of chromoluminarism. If colors in nature are juxtaposed and mixed in the "eye," not just the palette, then we are all dramatists of color and life, with responsibilities there entangled. Every perception sets for us a mission of feeling, thought, and connection. Even in such tiny moments of perception, we are offered the gift of an obliging, so to speak, a call to respond or give attention to whatever sense of spirit (Geist or pneuma) we face before or beyond Tracy's limit-question, "Why be ethical?"

I think that is why the last seconds of Sunday in the Park will move us, if we too can see "so many possibilities..." that George sees in a "blank page or canvas" (p. 202). Mandy Patinkin played this as an instant of insight, Jake Gyllenhaal as a moment of perplexity, perhaps of regret like Emily's. A regret I have is how the final tableau is specified, as the "characters from the painting" promenade again and take their places in "Sunday." I wish they were also their modernist counterparts from Act II, in 1980s-2000s dress but with the same slow movements and settling into their same positions in the painting. The isle of Grand Jatte and people there today are not without value; the greens are darker, the sky greyer, and the water muddier, George tells the spirit of Seurat's mother. "But the air is rich and full of light" (p. 200). 


\section{Conclusions}

That drama and religion connect through ritual must be qualified by the observation that theatrical drama comes into its own only when it is no longer ritual but, say, entertainment or education. ${ }^{56}$ Even when 'to entertain' deepens to 'discern attentively,' the ritual-drama relation can be a puzzle. Does ritual discern? Does entertainment ritualize? Well, 'both,' or 'sometimes,' no doubt. That issue aside, this essay proposes to understand religious dimensions in theatrical drama through concepts of limit. Limit experiences and questions speak to orientations and disorientations toward 'the real' as they become pertinent to theatre, ritual, and religious traditions. Metatheatrical relations can lead us to explore where embodied worlds and horizons meet, differentiate, overlap, and make claims on us. Theatrical drama invites, even impels, us to discern limits and 'otherwise' possibilities of life, together.

Metatheatre-3 is probably the hardest case for my claim, even though the mode registers the "histrionic sensibility" 57 of human experience. Namely, that (1) we 'play' or are 'played' by multiple social-personal roles and parts; (2) we enjoy imitating, for others, such play; and (3) we especially enjoy witnessing and learning from theatrical imitations. The word histrionic signals the problem. As with much theatre lingo transferred to life, it is pejorative, suggestive of feigned hyperbolic emotion, insincerity, or inauthenticity. The opposite insight, though equally old-that by rehearsing social parts to the point of in-habiting them we become who we are with and for one another-does not seem so quickly to come to mind. I sense antitheatrical bias in some performance theory that would expose a cultural achievement or some purported universal as being merely a power-inflected construct or illusion. Universals, however, straddle the difference between limit-to and limit-of. As Plato and Aristotle differently argued, universals are immanent in our particular constructs of experience, yet also transcend them, making our meanings finitely shareable. Metatheatricality explores this straddling of the limits 'to' and 'of' shared experience. Yet an unacknowledged preference for solitary authenticity is detectable in "Putting It Together." Most of its characters not only assume we should have no illusions, but that it would be better if our lives, somehow, were not contingently and artificially constructed, even though we know better. Ambivalent critiques of this sort neglect to explore possibilities of honestly collaborative constructs, in social life or in art. A construct can point beyond itself and give rise to feeling and thought.

Metatheatricality in Our Town can also seem antitheatrical in its minimalism. ("There's some scenery for those of you who think they have to have scenery.") Wilder's claim, however, is that by minimizing the smoke and mirrors and allowing us to see how they actually work, the play substantiates the universals it hopes we acknowledge but cannot 'see.' That is, life-transcending value-immanent "way down deep" in every moment and nexus of life-is made real through discernment and bodily proximity. We are to feel the weight of universals pressing on our skin as we are side by side with people constructing and querying them. In Sunday in the Park, the emphases on constructing and deconstructing are more elaborate; the play's bravura design both minimizes and maximizes the 'magic of theatre' and risks 'shorting out.' But in so doing, it reveals and values limits and possibilities in different ways than Our Town.

Our Town was so metaphysically confident in inherent, quotidian value that it could leave the ultimate limit-of unarticulated. We know only that as we wean from the cares of this world (limit-to), we await and prepare for "something" eternal. If, like Emily, the dead in their in-between state choose to see their finite interrelationships sub specie aeternitatis, it can be devastating, unless with a saint's eye or poet's. By contrast, Act II of Sunday in the Park has little metaphysical confidence as it exposes the pragmatics that puts art together. Yet Act I, which also shows art to be socially as well as aesthetically constructed, ${ }^{58}$ does have confidence in ordinary perception. It is in the eye and ear (limit-to) that

\footnotetext{
6 See Friedrich 1983.

57 Driver's phrase (1970), p. 262; his point is that technological modernity loses this impulse, to the detriment of drama.

58 McLaughlin 2016, p. 155.
} 
the performative universals—design, tension, harmony-mix to manifest the plethora of possibilities (limit-of). There, as the play ends on the island, a simpler magic of theatre allows us see, with George, a transcending 'more': Dot enters, there and now, across times and spaces. Sunday in the Park is confident that those among the living will perceive possibilities of love and art in the moving 'now,' sub species aeternitatis et theatrum.

Oh-just as I had a notion for restaging the Grand Jatte tableau at the end of Act II, I have one for the Chromolume. Be apophatic. Do not show the machine, not even its piercing lasers or dancing dots. ${ }^{59}$ Just show the faces of the guests being illuminated by light-I suggest a wash of bright but calm light, with quieter music - as they make of the Chromolume what they will, differently. Let their faces show the limits and possibilities of that new story.

Funding: This research received no external funding.

Conflicts of Interest: The author declares no conflict of interest.

\section{References}

Abel, Lionel. 1963. Metatheatre: A New View of a Theatrical Form. New York: Hill and Wang.

Abel, Lionel. 2003. Tragedy and Metatheatre: Essays in Theatrical Form. New York: Holmes and Meier.

Austin, John Langshaw. 1962. How to Do Things with Words. Cambridge: Harvard UP.

Bakhtin, Mikhail. 1981. Discourse and the Novel. In his The Dialogic Imagination. Translated by Caryl Emerson, and Michael Holquist. Austin: University of Texas Press.

Barish, Jonas. 1981. The Antitheatrical Prejudice. Berkeley: University of California Press.

Bell, Catherine. 1992. Ritual Theory, Ritual Practice. New York: Oxford UP.

Block, Jane. 2003. Pointillism. Oxford Art Online/Grove Art Online. Available online: https://doi.org/10.1093/gao/ 9781884446054.article.T068278 (accessed on 18 February 2020).

Bouchard, Larry D. 2009. Religion and Literature: Four Theses and More. Religion and Literature 41: 12-19.

Bouchard, Larry D. 2014. Dramatic Ways of Being Religious. In The Oxford Handbook of Religion and the Arts. Edited by Frank Burch Brown. New York: Oxford UP, pp. 162-81.

Brantley, Ben. 2002. Review of Our Town. New York Times, December 5, section E. 1-2.

Brantley, Ben. 2008. Review of Sunday in the Park with George. New York Times, December 2, Arts section.

Brantley, Ben. 2017. Review of Sunday in the Park with George. New York Times, February 23, section C. 5.

Brecht, Bertolt. 1966. Galileo. English version by Charles Laughton. Edited by Eric Bentley. New York: Grove Press.

Bryer, Jackson R. 2018. Thornton Wilder in Collaboration: Collected Essays on His Drama and Fiction. Edited by Jackson R. Bryer, Judith P. Hallett and Edyta K. Oczkowicz Newcastle Upon Tyne: Cambridge Scholars Publishing. Butler, Judith. 1990. Gender Trouble: Feminism and the Subversion of Identity. New York: Routledge.

Corrigan, Robert W. 1961. Thornton Wilder and the Tragic Sense of Life. Educational Theatre Journal 13: 167-73. [CrossRef]

Driver, Tom F. 1970. Romantic Quest and Modern Query: A History of Modern Theatre. New York: Delacorte Press.

Friedrich, Rainer. 1983. Drama and Religion. In Themes in Drama, No, 5: Drama and Religion. Edited by James Redmond. Cambridge: Cambridge UP.

Gadamer, Hans-Georg. 1989. Truth and Method, 2nd ed. Translated by Joel Weinsheimer, and Donald Marshall. New York: Crossroad.

Gates, Anita. 2002. Review of Our Town. New York Times, February 25, section E. 5.

Gillespie, Charles. 2019. Drama Alone is Credible: Hans Urs von Balthasar and the Interpretive Work of Theatre and Performance in Twentieth-Century Christian Thought. Charlottesville: University of Virginia dissertation.

Goffman, Erving. 1959. The Presentation of Self in Everyday Life. New York: Doubleday.

Goldstone, Richard H. 1975. Thornton Wilder: A Intimate Portrait. New York: Saturday Review Press.

59 The 2005/2008 revival directed by Buntrock, with digital scenery, did not show the machine directly; instead, colorful lights projected on the audience. See Brantley 2008, Arts section. 
Greenblatt, Stephen. 1998. Shakespearian Negotiations: The Circulation of Social Energy in Renaissance England. Berkeley: University of California Press.

Gussow, Mel. 1988. The Darker Shores of Thornton Wilder. New York Times, December 11, section H. 7, 37.

Harrison, Gilbert. 1983. The Enthusiast: A Life of Thornton Wilder. New Haven: Ticknor and Fields.

Healy, Patrick. 2010. Review of Our Town. New York Times, July 11, section AR. 1.

Herbert, Robert L. 1968. Neo-Impressionism. New York: Solomon R. Guggenheim Foundation.

Herbert, Robert, and Neil Harris. 2004. Seurat and the Making of La Grand Jatte. Chicago: Art Institute.

Isherwood, Christopher. 2009. Review of Our Town. New York Times, February 26, section C. 1.

Konkle, Lincoln. 2006. Thornton Wilder and the Puritan Narrative Tradition. Columbia: University of Missouri Press.

Konkle, Lincoln. 2018. Preparing the Way: Our Town and The Skin of Our Teeth as Proto-Postmodern Drama. In Thornton Wilder in Collaboration: Collected Essays on His Drama and Fiction. Edited by Jackson R. Bryer, Judith P. Hallett and Edyta K. Oczkowicz. Newcastle Upon Tyne: Cambridge Scholars Publishing, pp. 13-29.

Laster, Lori Ann. 2008. Welcome Back to Grover's Corners. American Theatre Magazine, May/June. 24-27.

McDonald, Macy. 2018. Thornton Wilder, American Existential Playwright: Our Town and Sartre's No Exit. In Thornton Wilder in Collaboration: Collected Essays on His Drama and Fiction. Edited by Jackson R. Bryer, Judith P. Hallett and Edyta K. Oczkowicz. Newcastle Upon Tyne: Cambridge Scholars Publishing, pp. 30-44.

McLaughlin, Robert. 2016. Stephen Sondheim and the Reinvention of the American Musical. Jackson: UP of Mississippi.

McNulty, Charles. 2017. Review of Our Town. Los Angeles Times. October 3. Available online: https: //www.latimes.com/entertainment/arts/la-et-cm-deaf-west-our-town-review-20171003-story.html (accessed on 18 February 2020).

Mudasir, Mufti. 2011. Language, Character and History in Postmodern Drama: Towards Formulating a Poetics. Criterion 2: 1-10.

Myers, Victoria. 2017. An Interview with Sarna Lapine. The Interval. March 28. Available online: https://www. theintervalny.com/interviews/2017/03/an-interview-with-sarna-lapine/ (accessed on 18 February 2020).

Niven, Penelope. 2012. Thornton Wilder: A Life. New York: HarperCollins.

Quigley, Austin E. 1985. The Modern Stage and Other Worlds. New York: Methuen.

Rich, Frank. 1988. Review of Our Town. New York Times, December 5, section C. 13.

Ricoeur, Paul. 1967. The Symbolism of Evil. Translated by Emerson Buchanan. Boston: Beacon.

Ricoeur, Paul. 1983. Time and Narrative. Translated by Kathleen McLaughlin, and Davis Pellauer. Chicago: University of Chicago Press, Vol. 1.

Scarry, Elaine. 1985. The Body in Pain: The Making and Unmaking of the World. New York: Oxford UP.

Secrest, Meryle. 1998. Stephen Sondheim: A Life. New York: Knopf.

Shapiro, Susan E. 1983. The Recovery of the Sacred: Hermeneutics and Theology after the Holocaust. Chicago: University of Chicago dissertation.

Shirley, Don. 2012. Review of Our Town. Los Angeles Stage Times Archive. January 23. Available online: https://thisstage.la/2012/01/a-former-simon-stimson-examines-broads-our-town-and-latc/ (accessed on 18 February 2020).

Sondheim, Stephen, and James Lapine. 1986. Sunday in the Park with George: A Musical. Music and lyrics by Stephen Sondheim. Edited by James Lapine. New York: Dodd and Mead.

Sondheim, Stephen. 2011. Look, I Made a Hat: Collected Lyrics (1981-2011) with Attendant Comments, Amplifications, Dogmas, Harangues, Digressions, Anecdotes and Miscellany. New York: Knopf.

States, Bert O. 1985. Great Reckonings in Little Rooms: On the Phenomenology of Theater. Berkeley: University of California Press.

Taylor, Mark C. 2004. Betraying Altizer. In Thinking through the Death of God: A Critical Companion to Thomas J. J. Altizer. Edited by Lissa McCollough and Brian Schroeder. Albany: State University of New York Press, pp. 11-29.

Tracy, David. 1975. Blessed Rage for Order: The New Pluralism in Theology. New York: Seabury.

Tracy, David. 1999. Fragments: The Spiritual Situation of Our Time. In God, the Gift, and Postmodernism. Edited by John D. Caputo and Michael J. Scranton. Bloomington: Indiana UP.

Turner, Victor. 1967. Betwixt and Between: The Liminal Period in Rites de Passage. In his The Forest of Symbols. Ithaca: Cornel UP, pp. 93-114.

Turner, Victor. 1974. Dramas, Fields, and Metaphors: Symbolic Action in Human Society. Ithaca: Cornell UP. 
Von Balthasar, Hans Urs. 1988. Theo-Drama: Theological Dramatic Theory. Translated by Graham Harrison. San Francisco: Ignatius Press, vol. 1, pp. 163-66.

Wilder, Thornton. 1957. Three Plays. New York: Harper and Row.

Zadan, Craig. 1986. Sondheim and Co, 2nd ed. New York: Harper and Row.

(C) 2020 by the author. Licensee MDPI, Basel, Switzerland. This article is an open access article distributed under the terms and conditions of the Creative Commons Attribution (CC BY) license (http://creativecommons.org/licenses/by/4.0/). 